\title{
Investigation of Soil Dynamic Behavior by Using Equivalental Linear Analysis Method: Example of Aksaray Doğantarla

\author{
Atila DEMIRÖZ, ${ }^{*}$ (D), Raziye BOZKURT ${ }^{\mathrm{b}}$
} \\ ${ }^{a, *}$ Konya Technical University Civil Engineering Department, 42000, KONYA, TURKEY \\ ${ }^{b}$ Konya Technical University Civil Engineering. Department, 42000, KONYA, TURKEY
}

\section{ARTICLE \\ INFO \\ Received: 15.04 .2020 \\ Accepted: 17.07.2020 \\ Keywords: \\ Aksaray, Earthquake, \\ Soil Dynamic \\ Behavior Analysis, \\ Equivalent Analysis \\ *Corresponding \\ Authors \\ e-mail: \\ ademiroz@ktun.edu.tr}

\begin{abstract}
Earthquake is a natural disaster type that deeply affects life. Although it differs according to the geotechnical properties of the ground, it can cause serious loss of life and property in some cases depending on the intensity of the earthquake. The vibration waves that occur with sudden breaks in the earth' s crust create an earthquake. The fact that the earthquake time and severity are not known in advance, the stratified and unknown structure of the ground makes the situation more complicated. For this reason, it is necessary to determine the earthquake properties correctly and take necessary measures in advance. Therefore, it is deemed appropriate to determine the dynamic behavior of the soil in case of an earthquake, by determining it with field and laboratory studies and making the necessary analyzes. For this purpose, many software programs have been developed. In the developed software programs, the required data can be entered into the system and the dynamic behavior of the ground can be analyzed seismically. In the light of this information, for the study of Aksaray Doğantarla, Turkey Building Seismic Code also suggested the equivalent dynamic behavior of the soil using linear analysis methods were investigated. Using the soundings and seismic studies in the region, the possible behavior of the soil at the time of the earthquake was interpreted.
\end{abstract}

https://dx.doi.org/10.30855/gmbd.2020.02.08

\section{Eşdeğer Doğrusal Analiz Yöntemi Kullanılarak Zemin Dinamik Davranışının İncelenmesi: Aksaray Doğantarla Örneği}

\begin{tabular}{l} 
MAKALE \\
BILGISI \\
\hline Alınma: 15.04 .2020 \\
Kabul: 17.07 .2020 \\
\hline \\
Anahtar Kelimeler: \\
Aksaray, Deprem, \\
Zeminin Dinamik \\
Davranış1, Eşdeğer \\
Doğrusal Analiz \\
"Sorumlu Yazar: \\
e-posta: \\
ademiroz@ ktun.edu.tr
\end{tabular}

\section{$\ddot{O} \mathbf{Z}$}

\begin{abstract}
Deprem canlı yaşamını derinden etkileyen doğal bir afet türüdür. Zeminin geoteknik özelliklerine göre farklılık göstermekle birlikte, bazı durumlarda deprem şiddetine bağlı olarak, ciddi can ve mal kayıplarına neden olabilmektedir. Yerkabuğunda oluşan ani kırılmalar ile ortaya çıkan titreşim dalgaları depremi meydana getirmektedir. Deprem zamanının ve şiddetinin önceden bilinememesi, zeminin tabakalı ve bilinmez yapısı, durumu daha karmaşık bir hale getirmektedir. $\mathrm{Bu}$ nedenle de zemin deprem özelliklerinin doğru tayin edilmesi ve gerekli tedbirlerin önceden alınması gerekir. Dolayısı ile ilgili zeminin herhangi bir deprem anında nasıl bir dinamik davranış sergileyeceği, arazi ve laboratuvar çalışmaları ile tahmin edilerek, gerekli analizlerin yapılmas gerekmektedir. $\mathrm{Bu}$ amaçla birçok bilgisayar programı da geliştirilmiştir. Geliştirilen bilgisayar programlarında gerekli veriler programa girilerek zeminin dinamik davranışı sismik olarak irdelenebilmektedir. Bu bilgiler 1şı̆̆ında, bu çalışma da Aksaray ili Doğantarla bölgesi için, Türkiye Bina Deprem Yönetmeliği’ nde önerilen, eşdeğer doğrusal analiz yöntemi kullanılarak bölge zemininin dinamik davranışı incelenmiştir. Bölgede yapılan sondajlar ve sismik çalışmalar kullanılarak, zeminin deprem anındaki olası davranışı yorumlanmıştır.
\end{abstract}

https://dx.doi.org/10.30855/gmbd.2020.02.08

Bu makaleye atıf yapmak için: A. Demiröz and R. Bozkurt, "Investigation of Soil Dynamic Behavior by Using Equivalental Linear Analysis Method: Example of Aksaray Doğantarla," Gazi Journal of Engineering Sciences, vol. 6, no. 2, pp. 160-171, August, 2020, doi: https://dx.doi.org/10.30855/gmbd.2020.02.08. 


\section{GIRISŞ (INTRODUCTION)}

The behavior of the earth under earthquake effect is of great importance in terms of life and property safety. For this reason, the ground should be subjected to necessary field and laboratory experiments and an idea should be obtained about behavior. Otherwise, loss of life and property may occur. Turkey Earthquake Building Regulations [1] based on dynamic analysis should be done on the ground against the effects of earthquakes. Shear wave velocity (Vs) is the most important parameter for dynamic analysis.

Earthquake effect is evaluated by using the data obtained from the analysis. Therefore, in this study, the parameters obtained using Doğantarla region, drilling data and seismic study results within Aksaray province boundaries were analyzed by equivalent linear analysis method. Seismicity of the region was interpreted with results. DeepSoil program was used to make equivalent linear analysis. Acceleration-time plots obtained in the analyzed were evaluated.

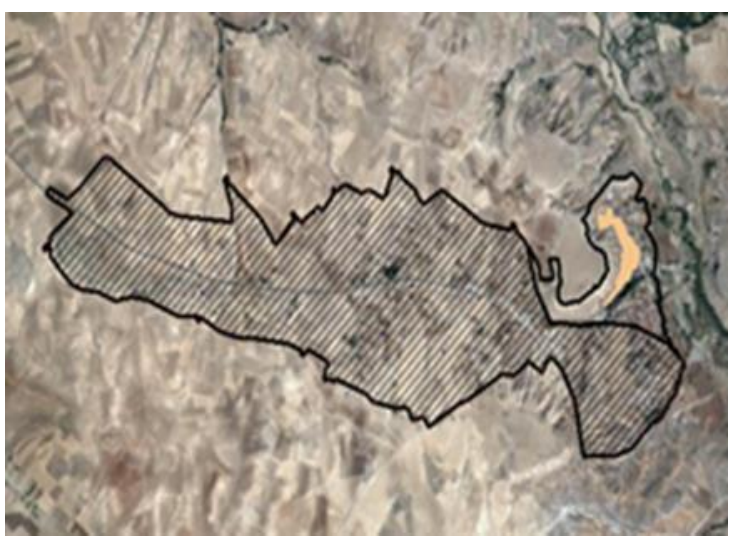

Figure 1. Satellite view of the investigation area (Inceleme alaninin uydu görünümü)

\section{GENERAL FEATURES OF THE EXAMINATION AREA (INCELEME ALANININ GENEL ÖZELLIKLERI)}

It is located in the Middle Kizılırmak section of the Central Anatolia region of Aksaray province, southeast of Tuz Lake. It consists of the volcanic mountains and plateaus and plains formed by lava coming from the mountains. Aksaray province and Doğantarla region covers an area of approximately 530.18 hectares. The region was established on a rocky and hill terrain. The region is surrounded by agricultural land and the area has a sloping structure towards the east.

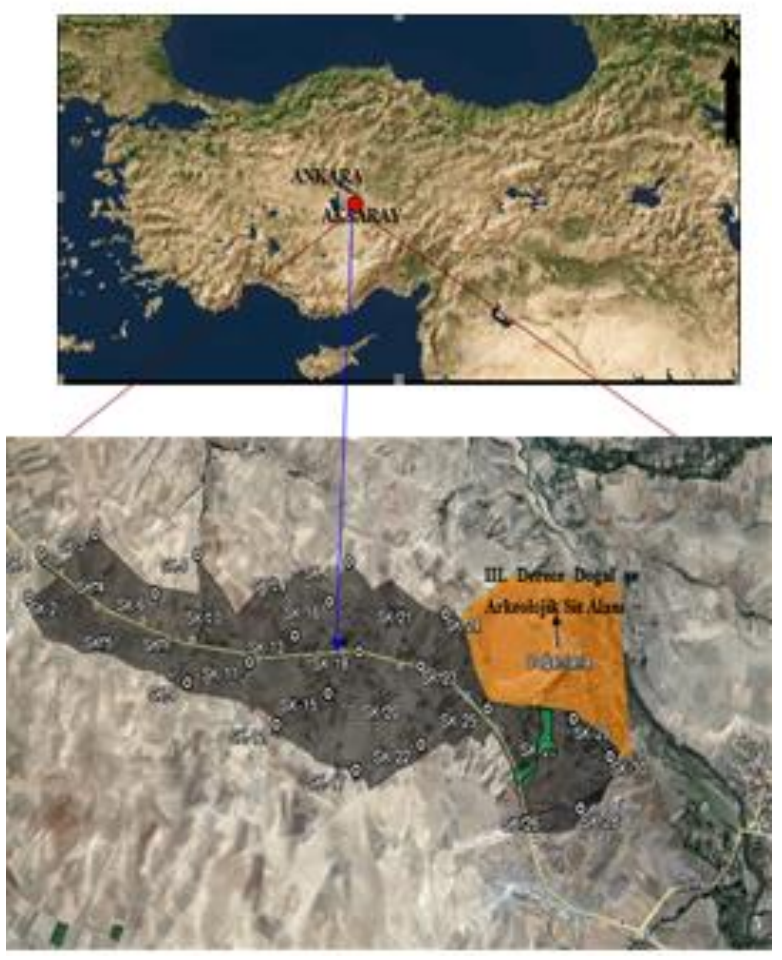

Figure 2. Location map of the study area and representation of sounding locations (Inceleme alanin yer bulduru haritası ve sondaj yerlerinin gösterimi)

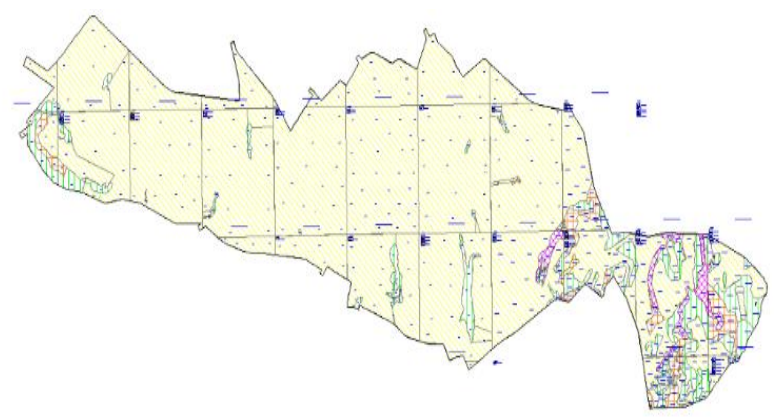

Figure 3. Investigation area scaled map (inceleme alan ölçeksiz haritasl)

\subsection{General Geology of The Investigation Area (Inceleme Alaninin Genel Jeolojisi)}

Many studies have been carried out in Aksaray province in order to determine the geological features. The ground profile maps were prepared by interpreting the data obtained from the studies.

The units on the maps are from old to young, light gray and white colored Bozçaldağ Formation $(\mathrm{Pb})$, Mezas Formation (Tm) containing Mamasin Ophiolitic (Ko), conglomerate, red sandstone and fine claystone, green volcanic origin. Uzunkaya Formation consisting of sandstone and claystone, Melendiz Volcanites (Tmv), Selime Tuffs (Ts), gray-colored 
Kızılkaya Ignimbrite (Tk), Demonstrated Volcanics, hard and homogeneous Sarımadentepe Member (Tmüsa), İnsuyu Formation (Tmi) seen around Tuz Lake, Travertine (Qtr) can be listed as Alluvium (Qal). The fault structure in the region is in NW-SE and NE-SW direction.

\section{Geotechnical Field Studies (Geoteknik Arazi Çalışmaları)}

A total of 30 basic wells were drilled in the study area at depths of $7.5 \mathrm{~m}, 10 \mathrm{~m}$ and [2]. As a result of the studies, it was aimed to determine the geology, engineering properties, groundwater condition and geotechnical parameters of the study area. In addition, 10 Seismic Refractions were carried out in the study area, which gave the dynamic-elastic engineering parameters of the ground, layer thicknesses, ground classes, ground vibration periods and ground magnifications. There is no landslide danger in the region.

Laboratory Experiments for Geotechnical Purposes (Geoteknik Amaçlı Laboratuvar Deneyleri)

\section{Physical Properties of the Ground (Zeminin Fiziksel Özellikleri)}

A large part of the study area consists of rocky ground. There is silty sandy ground on a rocky ground only in one part of the study area. UD sample was taken from this ground. However, it does not have a significant effect since it is a very thin layer during construction.

\section{Mechanical Properties of Soil (Zeminin Mekanik Özellikleri)}

Since most of the ground consists of rock layers, no study has been done to determine mechanical properties of the soils.

\section{Permeability (Permeabilite)}

Depending on the nature of the ground, the condition of holding groundwater differs. The ability of a fluid to pass through a void environment is called permeability. The movement of the fluid in the soil depends on the pore structure of the soil. Since the basic unit of the study area consists of tuff-borne rocks, permeability has been investigated.

\section{Rock Mechanics Experiments (Kaya Mekaniği Deneyleri)}

The point loading strength index (Is) was determined from the results of the point loading test performed on 49 core samples of 30 drillings performed in the study area in order to classify according to the rock resistance.

There is a correlation between Is and point loading compression strength as $\sigma c=C^{*}$ Is. As a result of the studies the Is values of rock soils representing tuffs vary between $2.09 \mathrm{~kg} / \mathrm{cm}^{2}$ and $38.5 \mathrm{~kg} / \mathrm{cm}^{2}$. TCR and RQD values of core samples were calculated.

$\mathrm{TCR}=$ (Total length of core pieces in the federate $) \times 100 /$ Feed length

$\mathrm{RQD}=$ (Core length of $10 \mathrm{~cm}$ and larger in advance) $\times 100 /$ Feed length

TCR: Total Core Yield

RQD: Rock Quality Indicator

In the relevant region, rock soil; The RQD value ranges from 0 to $23.33 \%$ and TCR values range from 12.12 to $94.00 \%$.

\section{Geophysical Studies (Jeofizik Çalışmalar)}

In the scope of Geological-GeophysicalGeotechnical studies in the Doğantarla region, seismic refraction studies were carried out in order to determine the dynamic-elastic engineering parameters of the soil, layer thicknesses and ground classes according to earthquake regulations. 10 seismic refraction results were obtained. In seismic refraction, the aim is to naturally define the elastic parameters of the ground between the layer by artificially shaking the ground. The longitudinal $(\mathrm{P})$ waves transmitted through the layers are small amplitude and high frequency and fast propagating waves. Transverse (S) waves are large amplitude and low frequency waves propagating at low speeds. Parameters such as the density of the environment, water content and the degree of cementing are factors affecting the wave velocity. As a result of seismic studies, stratification, dynamic-elastic engineering properties, ground classes, vibration periods, shear wave velocities, ground magnifications and discontinuities can be determined. $\mathrm{P}$ and $\mathrm{S}$ wave velocities were measured in 10 profiles. Approximate inspection depth is $20 \mathrm{~m}$. The figure below is an image of profiles. 


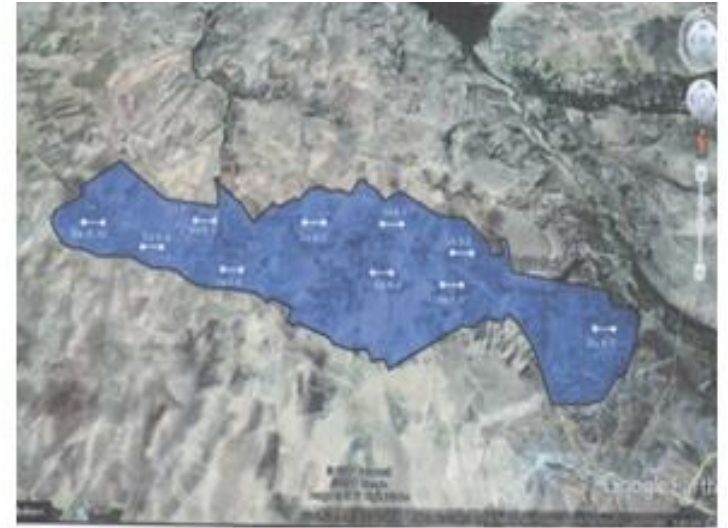

Figure 4. Satellite image of seismic studies (Yapılan sismik çalışmaların uydu görüntüsü)

Table 1. $\mathrm{V}_{\mathrm{p}}, \mathrm{V}_{\mathrm{s}}$ and $\mathrm{V}_{\mathrm{s}, 30}$ values of the study area (Inceleme alanının $V_{p}, V_{s}$ ve $V_{s, 30}$ hiz değerleri)

\begin{tabular}{|c|c|c|c|c|}
\hline $\begin{array}{c}\text { Size } \\
\text { Number }\end{array}$ & $\begin{array}{c}\text { Layer } \\
\text { Number }\end{array}$ & $\mathrm{V}_{\mathrm{p}}$ & $\mathrm{V}_{\mathrm{s}}$ & $\mathrm{V}_{\mathrm{s}, 30}$ \\
\hline \multirow{2}{*}{ Sis K-1 } & 1 & 383 & 193 & \multirow{2}{*}{748} \\
\hline & 2 & 1614 & 1080 & \\
\hline \multirow{2}{*}{ Sis K-2 } & 1 & 378 & 259 & \multirow{2}{*}{657} \\
\hline & 2 & 1607 & 832 & \\
\hline \multirow{2}{*}{ Sis K-3 } & 1 & 341 & 202 & \multirow{2}{*}{701} \\
\hline & 2 & 1899 & 979 & \\
\hline \multirow{2}{*}{ Sis K-4 } & 1 & 322 & 197 & \multirow{2}{*}{708} \\
\hline & 2 & 1705 & 1042 & \\
\hline \multirow{2}{*}{ Sis K-5 } & 1 & 524 & 268 & \multirow{2}{*}{900} \\
\hline & 2 & 2228 & 1220 & \\
\hline \multirow{2}{*}{ Sis K-6 } & 1 & 537 & 251 & \multirow{2}{*}{587} \\
\hline & 2 & 1154 & 728 & \\
\hline \multirow{2}{*}{ Sis K-7 } & 1 & 318 & 157 & \multirow{2}{*}{631} \\
\hline & 2 & 1660 & 915 & \\
\hline \multirow{2}{*}{ Sis K-8 } & 1 & 342 & 256 & \multirow{2}{*}{725} \\
\hline & 2 & 1775 & 901 & \\
\hline \multirow{2}{*}{ Sis K-9 } & 1 & 520 & 250 & \multirow{2}{*}{860} \\
\hline & 2 & 1865 & 1269 & \\
\hline \multirow{2}{*}{ Sis K-10 } & 1 & 445 & 259 & \multirow{2}{*}{833} \\
\hline & 2 & 1772 & 1119 & \\
\hline
\end{tabular}

\section{Classification of Soil Types (Zemin Türlerinin Sinıflandirılmast)}

As a result of the studies carried out in the study area, the units located across the ground are SC and GC group silty sands and silty pebbles. The soil group B for the ground units located is the local soil class Z2. Separated tuffs with fractured cracks were observed in the study area. It has a massive appearance and is decomposed near the surface. The tuffs found constitute the engineering zones and ground profile.

Dynamic-Elastic Parameters of Soil (Zeminin Dinamik-Elastik Parametreleri)
The parameters that control the volume and unit change of the soil are called dynamic-elastic parameters. Dynamic-elastic parameters are the parameters that most affect the deformations of rocks and soils. These parameters controlling the elastic properties of the medium can be listed as follows; density $(\rho)$, maximum shear modulus $\left(\mathrm{G}_{\max }\right)$, dynamic elasticity modulus $\left(\mathrm{E}_{\mathrm{d}}\right)$, bulk modulus $(\mathrm{K})$ and poisson ratio (v) [3].

$G_{\max }=325 N_{60}^{0,68}$

(1)

$\mathrm{G}_{\text {max }}$ : Maximum shear modulus

$\mathrm{N}_{60}:$ SPT $\mathrm{N}$ value

$E_{d}$ value is found by knowing $P$ and $S$ wave velocities and intensity values. It is a sign of the hardness and robustness of geotechnical sciences.

$E_{d}=\left[\left(3 V_{p}-4 V_{s}\right) /\left(V_{p}-V_{s}\right)\right] V_{s}$

$\mathrm{E}_{\mathrm{d}}$ : Dynamic elasticity modulus

$\mathrm{V}_{\mathrm{s}}$ : $\mathrm{S}$ wave velocity

$\mathrm{V}_{\mathrm{p}}$ : $\mathrm{P}$ wave velocity

$\mathrm{K}$ is a measure of the resistance of a material to compressibility. The results obtained are given in the table below.

(3) $=\frac{E}{3(1-2 v)}$

$\mathrm{K}$ : Bulk modulus, E: Elasticity modulus, $v$ : Poisson ratio

Table 2. Dynamic-elastic engineering parameters of the study area (Inceleme alaninin dinamik-elastik mühendislik parametreleri)

\begin{tabular}{|c|c|c|c|c|}
\hline $\begin{array}{c}\text { Size } \\
\text { Number }\end{array}$ & $\begin{array}{c}\text { Layer } \\
\text { Number }\end{array}$ & $\mathbf{G}_{\mathbf{m a x}}$ & $\mathbf{E}_{\mathbf{d}}$ & $\mathbf{K}$ \\
\hline \multirow{2}{*}{ Sis-1 } & 1 & 510 & 1357 & 1329 \\
\cline { 2 - 5 } Sis-2 & 2 & 22883 & 50096 & 20596 \\
\cline { 2 - 5 } & 1 & 916 & 1936 & 729 \\
\hline \multirow{2}{*}{ Sis-3 } & 1 & 13566 & 35730 & 32522 \\
\cline { 2 - 5 } & 2 & 543 & 1335 & 823 \\
\hline \multirow{2}{*}{ Sis-4 } & 1 & 19584 & 51662 & 47573 \\
\cline { 2 - 5 } & 2 & 21595 & 1222 & 681 \\
\hline \multirow{2}{*}{ Sis-5 } & 1 & 1064 & 2814 & 26026 \\
\cline { 2 - 5 } & 2 & 31652 & 81400 & 63359 \\
\hline \multirow{2}{*}{ Sis-6 } & 1 & 939 & 2554 & 3045 \\
\cline { 2 - 5 } & 2 & 9561 & 22363 & 11277 \\
\hline \multirow{2}{*}{ Sis-7 } & 1 & 322 & 863 & 892 \\
\cline { 2 - 5 } Sis-8 & 2 & 16541 & 42404 & 32388 \\
\hline \multirow{2}{*}{} & 1 & 872 & 1505 & 394 \\
\hline
\end{tabular}




\begin{tabular}{|c|c|c|c|c|}
\hline & 2 & 16310 & 43268 & 41552 \\
\hline \multirow{2}{*}{ Sis-9 } & 1 & 924 & 2494 & 2765 \\
\cline { 2 - 5 } & 2 & 32756 & 70027 & 27075 \\
\hline \multirow{2}{*}{ Sis-10 } & 1 & 954 & 2372 & 1544 \\
\cline { 2 - 5 } & 2 & 25146 & 58760 & 29530 \\
\hline
\end{tabular}

\section{$\mathbf{V}_{\mathrm{s}, 30}$ Speed $\left(V_{s, 30} H z z l\right)$}

In addition to the general physical properties of the soil, shear wave velocities should be determined in order to know its seismic behavior during earthquake. The complex structure of the soil affects its properties [4]. $\mathrm{V}_{\mathrm{s} 30}$ shear wave velocity of the soil at a depth of $30 \mathrm{~m}$ has been accepted as the main parameter properties [5]. Soil classification can be made by using $\mathrm{V}_{\mathrm{s} 30}$ shear wave velocity [6].

Table 3. Soil classification according to NEHRP (NEHRP' ye göre zemin sinfflandirlmasl)

\begin{tabular}{|c|c|c|}
\hline $\begin{array}{c}\text { Ground } \\
\text { Class }\end{array}$ & Definition & Specifications \\
\hline A & Hard Rock & $\mathrm{V}_{\mathrm{s}}>1500$ \\
\hline B & Rock & $\mathbf{7 6 0}<\mathrm{V}_{\mathrm{s}}<\mathbf{1 5 0 0}$ \\
\hline C & $\begin{array}{c}\text { Very Firm/Hard Ground } \\
\text { or Soft Rock }\end{array}$ & $\mathbf{3 6 0}<\mathrm{V}_{\mathrm{s}}<\mathbf{7 6 0}$ \\
\hline $\mathrm{D}$ & Hard/Firm Ground & $180<\mathrm{V}_{\mathrm{s}}<360$ \\
\hline E & Weak Ground & $\mathrm{V}_{\mathrm{s}}<180$ \\
\hline $\mathrm{V}_{\mathrm{s}}: 30 \mathrm{~m}$ Average shear wave velocity in depth $-\mathrm{V}_{\mathrm{s} 30}(\mathrm{~m} / \mathrm{sn})$ \\
\hline
\end{tabular}

Table 4. Soil classification according to TS EN 19981 (Eurocode 8) (TS EN 1998-1'e (Eurocode 8) göre zemin sinfflandirmast) [7]

\begin{tabular}{|c|c|c|}
\hline $\begin{array}{c}\text { Ground } \\
\text { Class }\end{array}$ & Definition & Specifications \\
\hline A & $\begin{array}{c}\text { Rock or other rock-like } \\
\text { formations }\end{array}$ & $\mathbf{V}_{\mathrm{s}}>\mathbf{8 0 0}$ \\
\hline B & $\begin{array}{c}\text { Too Tight Sand Gravel or } \\
\text { Too Hard Clays }\end{array}$ & $\mathbf{3 6 0}<\mathbf{V}_{\mathrm{s}}<\mathbf{8 0 0}$ \\
\hline C & $\begin{array}{c}\text { Tight or Medium Tight Sand, } \\
\text { Gravel or Hard Clay }\end{array}$ & $180<\mathrm{V}_{\mathrm{s}}<360$ \\
\hline D & $\begin{array}{c}\text { Cohesionless Floor from Loose } \\
\text { to Medium Tight or Cohesive } \\
\text { Ground from Soft to Hard }\end{array}$ & $\mathrm{V}_{\mathrm{s}}<180$ \\
\hline $\mathrm{V}_{\mathrm{s}}: 30 \mathrm{~m}$ Average shear wave velocity in depth $-\mathrm{V}_{\mathrm{s} 30}(\mathrm{~m} / \mathrm{sn})$ \\
\hline \multicolumn{3}{|c}{} \\
\hline
\end{tabular}

Table 5. Soil group according to NEHRP-UBC and TS EN 1998-1 design codes (NEHRP-UBC ve TS EN 1998-1 tasarım kodlarına göre zemin sınıflandırması)

\begin{tabular}{|c|c|c|c|}
\hline $\begin{array}{c}\text { Size } \\
\text { Number }\end{array}$ & $\begin{array}{c}\text { Vs } \mathbf{s}_{\mathbf{3 0}} \\
(\mathbf{m} / \mathbf{s n})\end{array}$ & NEHRP-UBC & TS EN 1998-1 \\
\hline Sis-1 & 748 & $\mathrm{C}$ & B \\
\hline Sis-2 & 657 & $\mathrm{C}$ & B \\
\hline Sis-3 & 701 & $\mathrm{C}$ & B \\
\hline Sis-4 & 708 & $\mathrm{C}$ & B \\
\hline Sis-5 & 900 & $\mathrm{~B}$ & B \\
\hline Sis-6 & 587 & $\mathrm{C}$ & B \\
\hline Sis-7 & 631 & $\mathrm{C}$ & B \\
\hline Sis-8 & 725 & $\mathrm{C}$ & \\
\hline
\end{tabular}

\begin{tabular}{|c|c|c|c|}
\hline Sis-9 & 860 & B & A \\
\hline Sis-10 & 833 & B & A \\
\hline
\end{tabular}

As a result of the studies carried out in the relevant region, the general soil class has been accepted as B. Local soil class has been determined as Z2.

\section{Groundwater Status (Yeralt Suyu Durumu)}

Groundwater was determined that the groundwater level started at 50 meters.

\section{ANALYSIS of SOIL DYNAMIC BEHAVIOR of THE EXAMINATION AREA (INCELEME ALANININ ZEMIN DINAMIK DAVRANIŞININ ANALIZI)}

The region is located in the 5th degree earthquake zone. As it is known, building safety is extremely important under the effect of earthquake. Seismicity of the region was investigated by using the results of the field and laboratory studies conducted within the scope of this study. DeepSoil is under development at the University of Illinois at Urbana-Champaign [8]. Using the DeepSoil program, Doğantarla region was analyzed using the equivalent linear analysis method, the spectral acceleration and soil magnification values of the soil were calculated, graphically defined and the soil dynamic behavior was interpreted.

\subsection{DeepSoil Program and Equivalent Linear Analysis (DeepSoil Programı ve Eşdeğer Doğrusal Analiz)}

DeepSoil program, which can perform linear and nonlinear ground behavior analyzes in the time domain, together with one-dimensional linear and equivalent linear analysis in the frequency domain, gives the spectral acceleration-time values of the ground using parameters [9]. It is also a program that enables liquefaction analysis. DeepSoil program is a multi-stage and one-dimensional ground response analysis program. In the analysis part, earthquake records, which were observed in previous years and caused great damage, are used.

In this study, using the sounding data of Doğantarla region, thicknesses of the layers, soil class, unit volume weight of the soil and shar wave velocity of the soil were recorded in the program. Then, taking into consideration the material properties of the soil, a selection was made from the empirical formulas registered. In addition, the damping ratio must be entered in order to calculate the response spectrum in the frequency domain. 
The damping ratio value was chosen as $5 \%$. In the study, it was analyzed at the bedrock level using 1999 Kocaeli earthquake record data.

\subsubsection{Equivalent Linear Analysis Results and} Discussion (Eşdeğer Doğrusal Analiz Sonuçları ve Tartışma)

In many studies, equivalent linear analysis method is recommended to investigate the seismicity of the region. [10]. The force acting on the ground must be damped by the ground to prevent deformations after the earthquake. However, this situation is complicated to understand. Because ground behavior cannot be determined exactly. The ground can absorb the effect of the earthquake force that it affects, but it cannot meet and transmit it to different layer by enlarging the effect.

This situation has an increasing effect on earthquake intensity. Using the shear wave velocity $\left(\mathrm{V}_{\mathrm{s}}\right)$ values obtained as a result of seismic studies, analyzes were made in the DeepSoil program and as a result, the ground magnification values were examined. Acceleration-time graphs, amplification-period, spectrum-period graphs were obtained with equivalent linear analysis using the previously mentioned 10 seismic study data and ground general properties. The graphics reflect ground dynamic behavior.

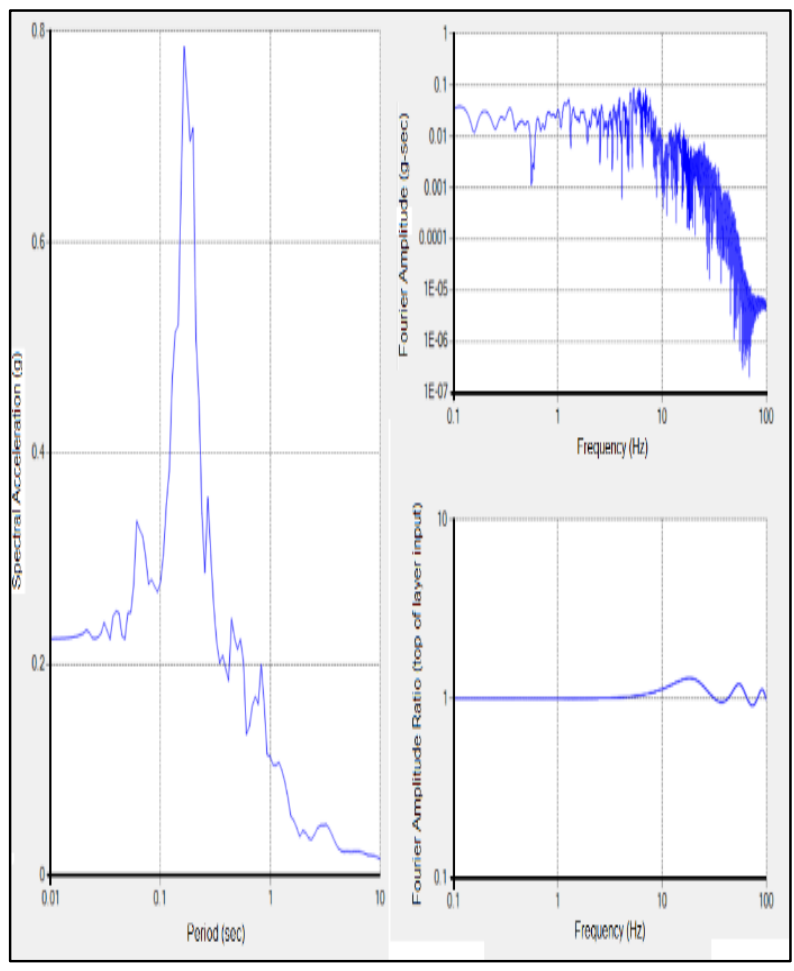

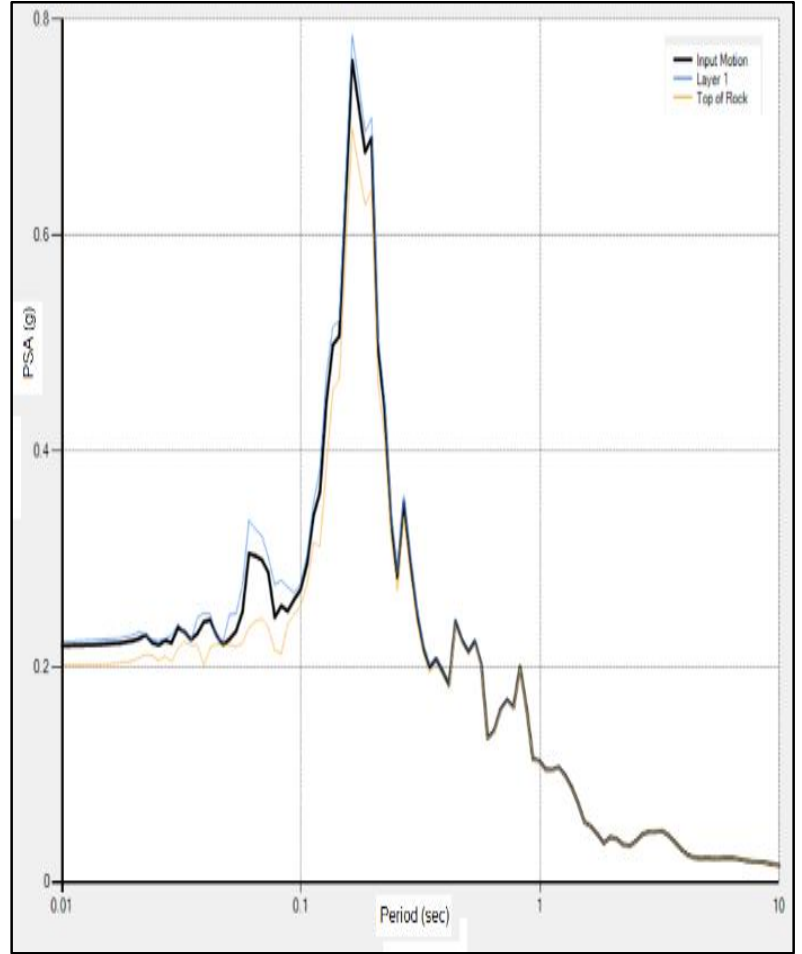

Figure 5. Spectrum-Period, Amplification-Period and PSA-Period plots of Doğantarla region Sis-1 data using Kocaeli earthquake records (Doğantarla bölgesi SisI'e ait verilerin, Kocaeli deprem kayttlar kullanılarak elde edilen Spektrum-Periyot, Amplifikasyon-Periyot ve PSA-Periyot grafikleri)

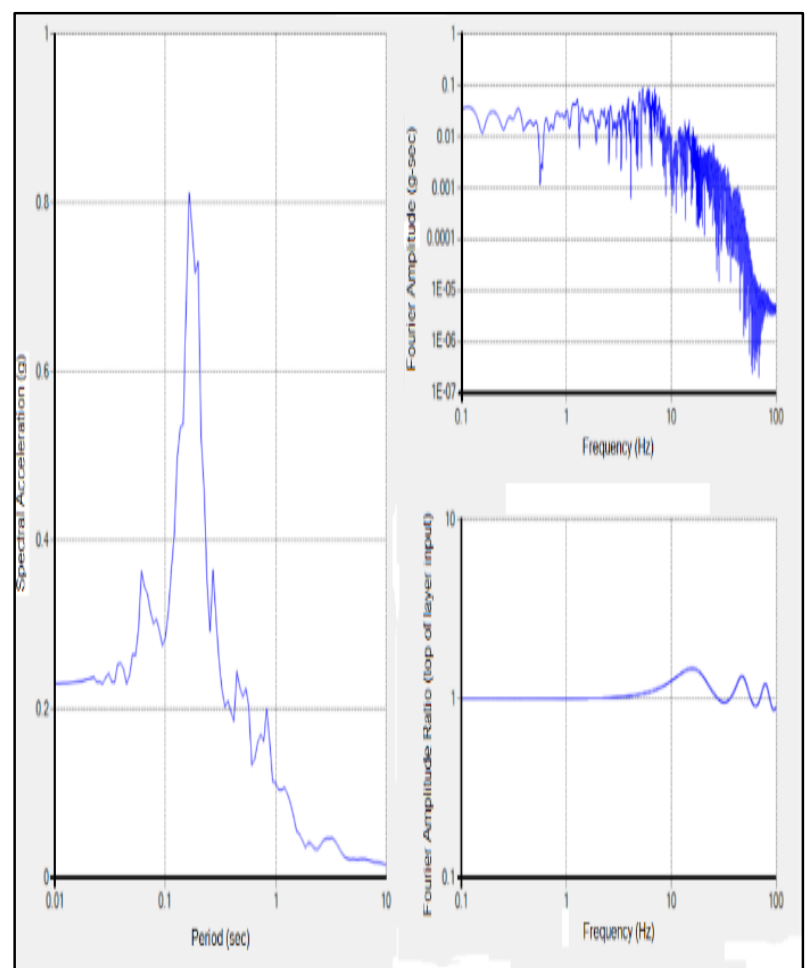




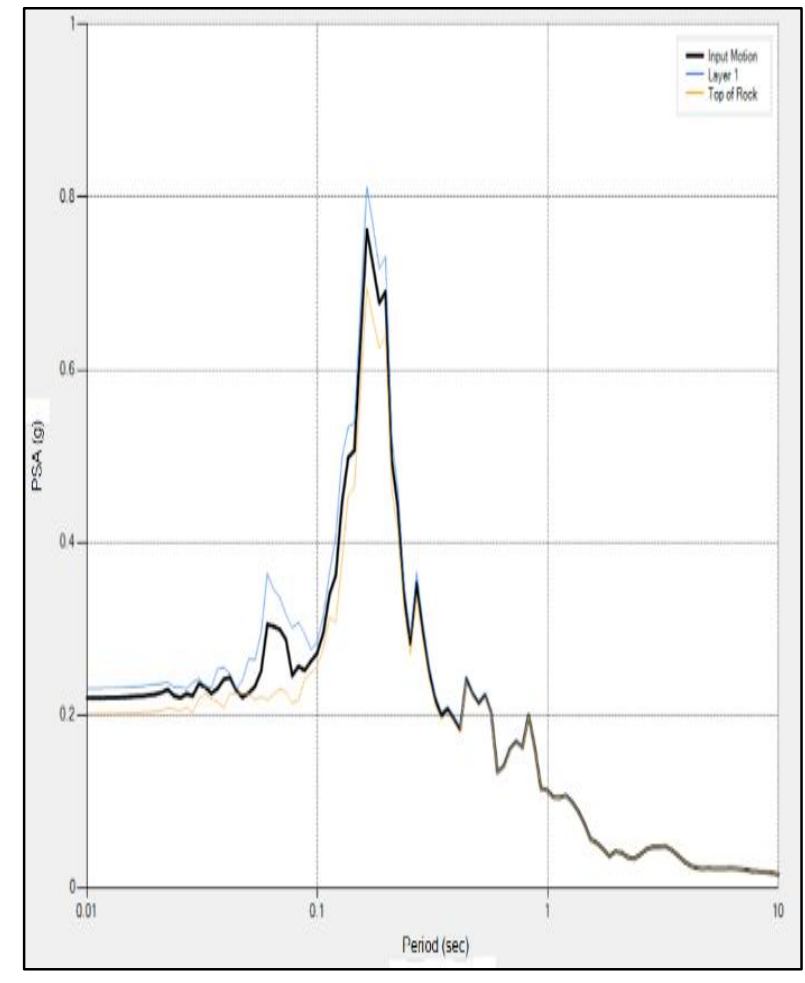

Figure 6. Spectrum-Period, Amplification-Period and PSA-Period plots of Doğantarla region Sis-2 data using Kocaeli earthquake records (Doğantarla bölgesi Sis2'ye ait verilerin, Kocaeli deprem kayttlar kullanılarak elde edilen Spektrum-Periyot, Amplifikasyon-Periyot ve PSA-Periyot grafikleri)

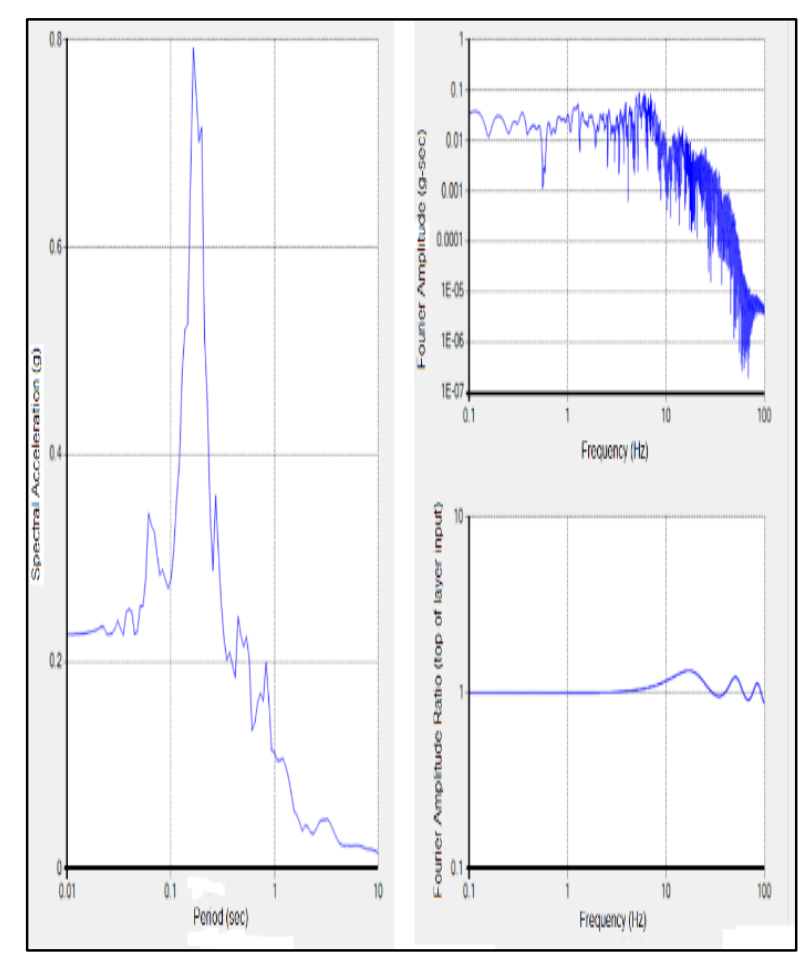

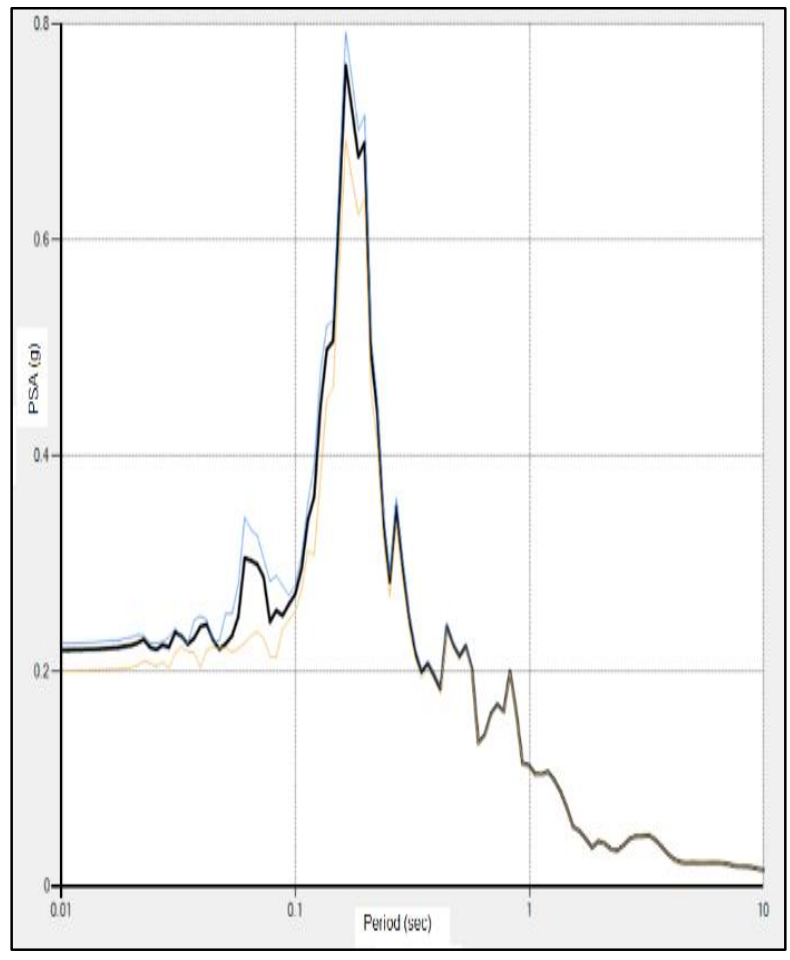

Figure 7. Spectrum-Period, Amplification-Period and PSA-Period plots of Doğantarla region Sis-3 data using Kocaeli earthquake records (Doğantarla bölgesi Sis3'e ait verilerin, Kocaeli deprem kayttları kullanılarak elde edilen Spektrum-Periyot, Amplifikasyon-Periyot ve PSA-Periyot grafikleri)

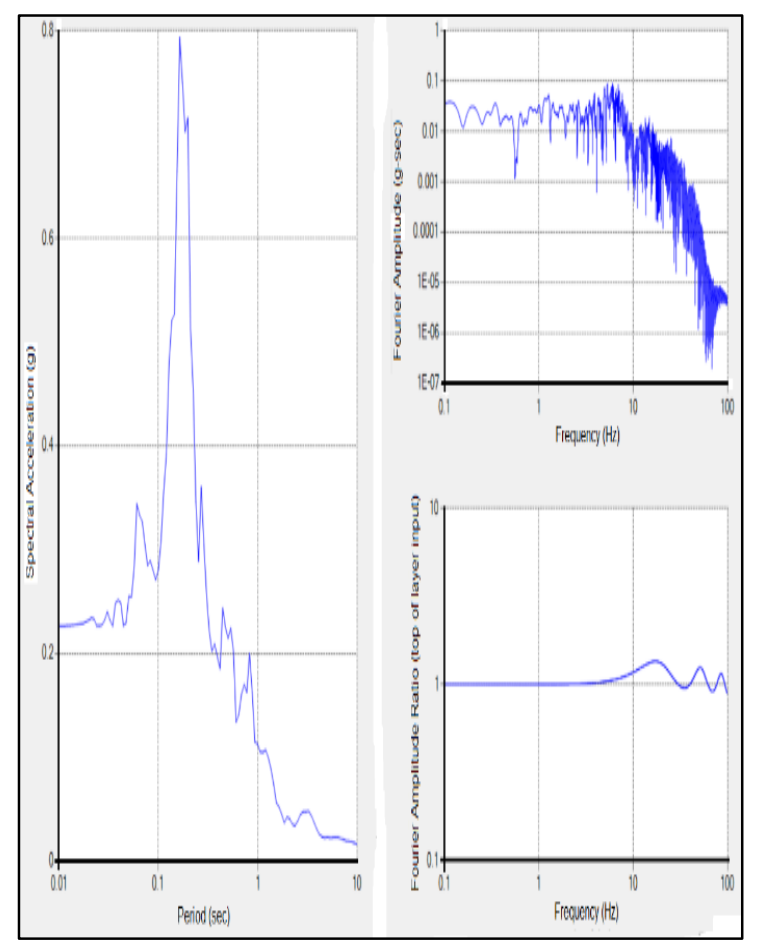




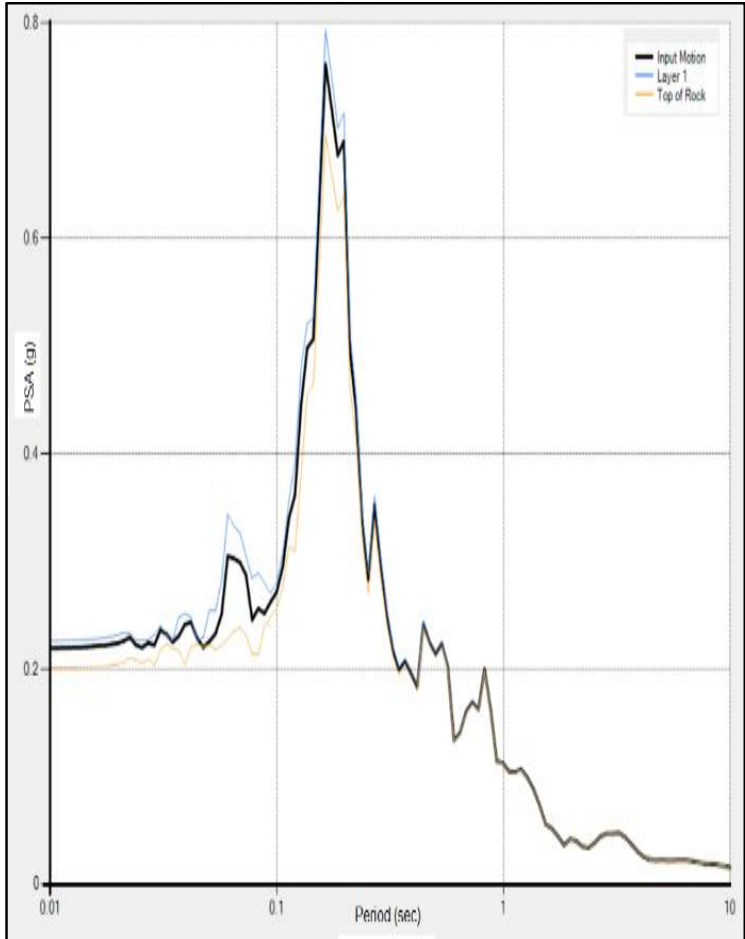

Figure 8. pectrum-Period, Amplification-Period and PSA-Period plots of Doğantarla region Sis-4 data using Kocaeli earhquake records (Doğantarla bölgesi Sis4'e ait verilerin, Kocaeli deprem kayttlar kullanilarak elde edilen Spektrum-Periyot, Amplifikasyon-Periyot ve PSA-Periyot grafikleri)

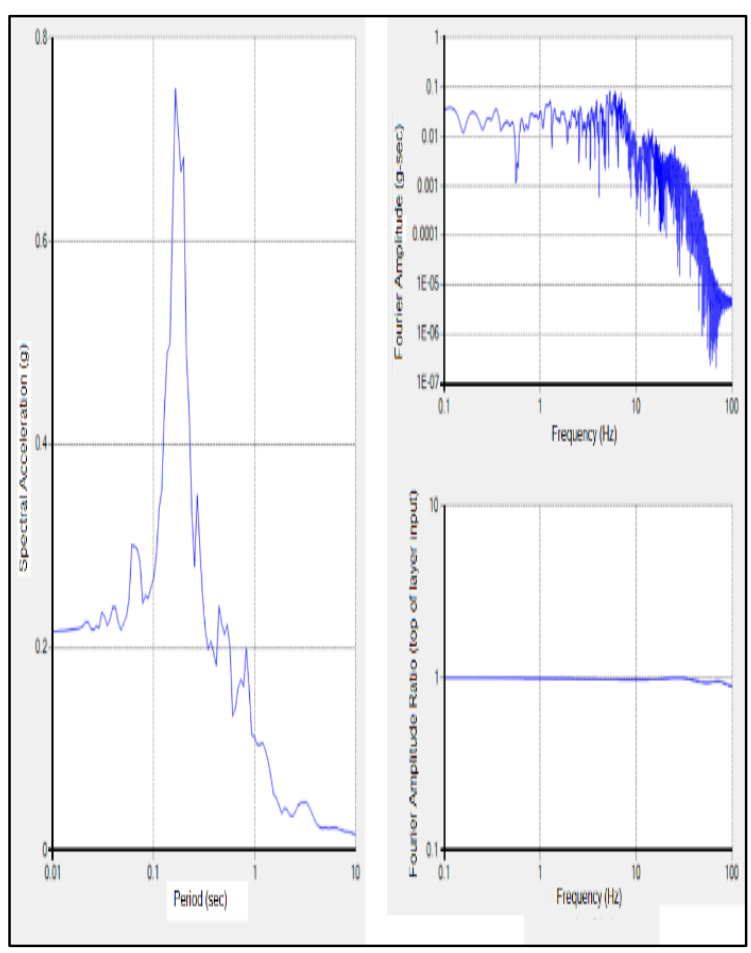

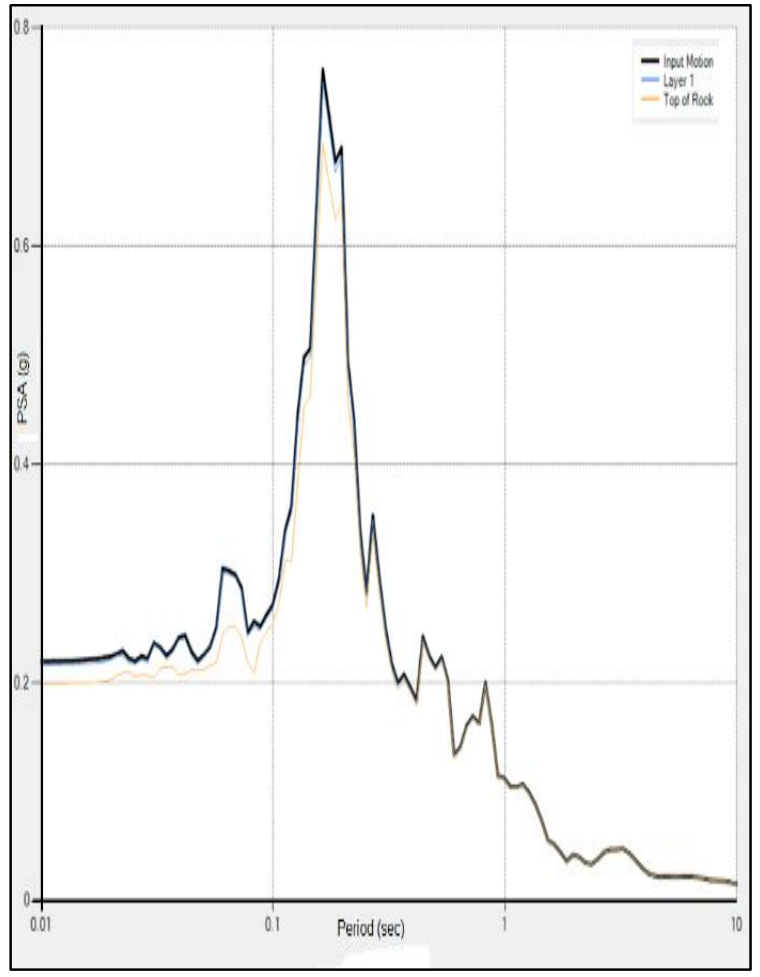

Figure 9. Spectrum-Period, Amplification-Period and PSA-Period plots of Doğantarla region Sis-5 data using Kocaeli earthquake records (Doğantarla bölgesi Sis5 ' e ait verilerin, Kocaeli deprem kaytları kullanılarak elde edilen Spektrum-Periyot, Amplifikasyon-Periyot ve PSA-Periyot grafikleri)

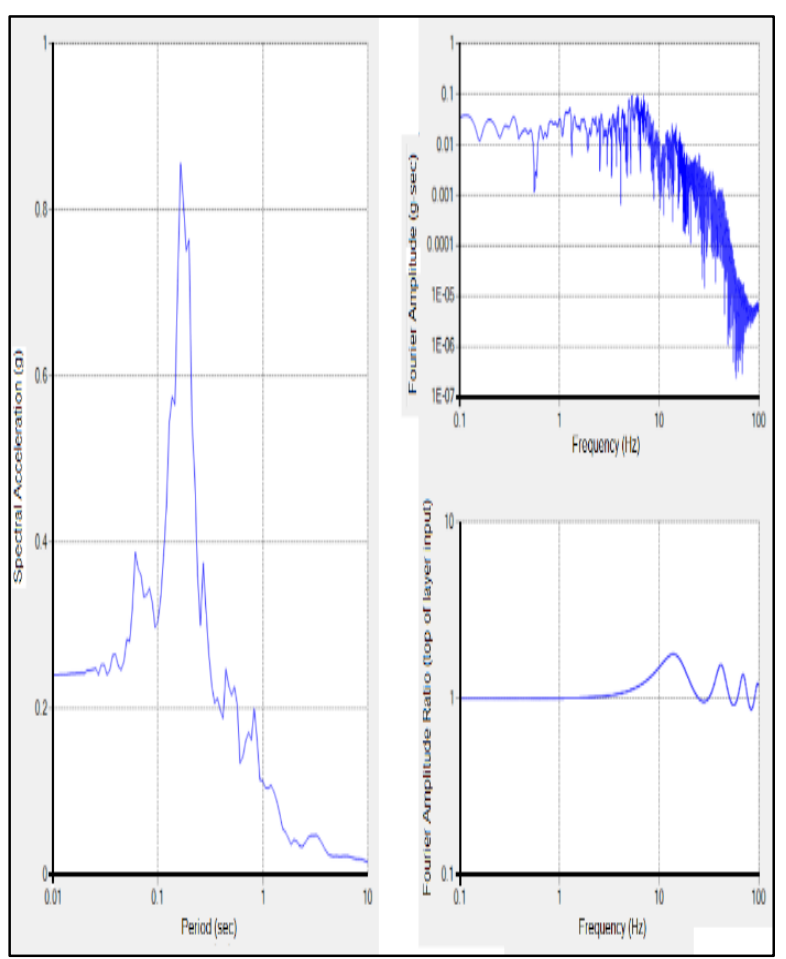




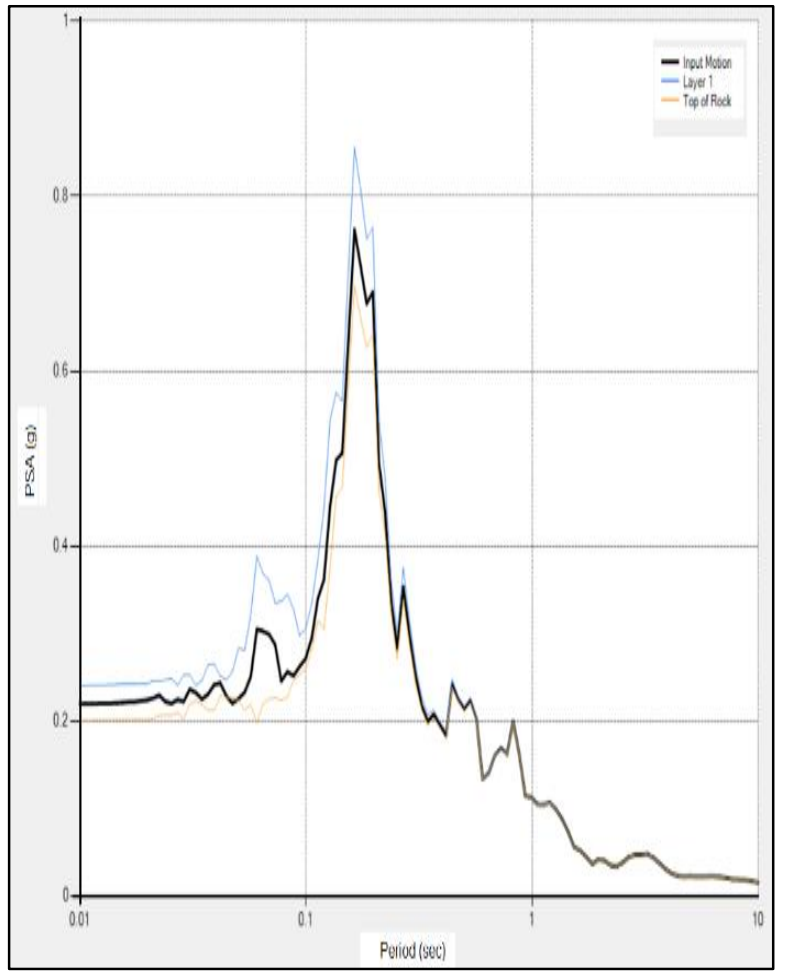

Figure 10. Spectrum-Period, Amplification-Period and PSA-Period plots of Doğantarla region Sis-6 data using Kocaeli earthquake records (Doğantarla bölgesi Sis 6'ya ait verilerin, Kocaeli deprem kayttlar kullanılarak elde edilen Spektrum-Periyot, Amplifikasyon-Periyot ve PSA-Periyot grafikleri)

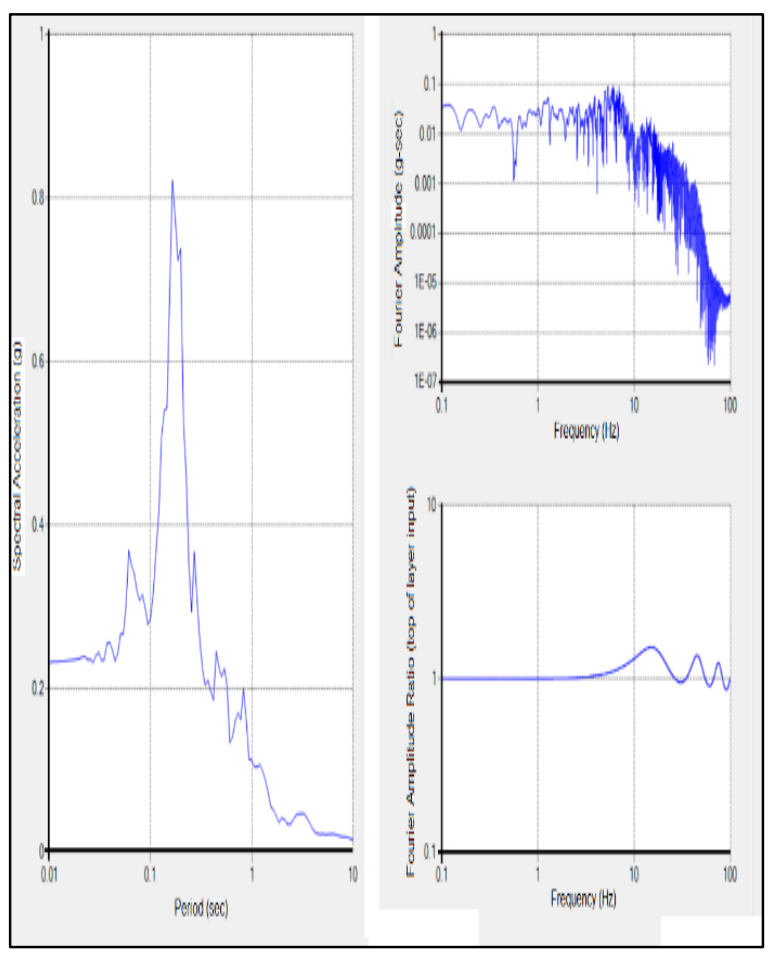

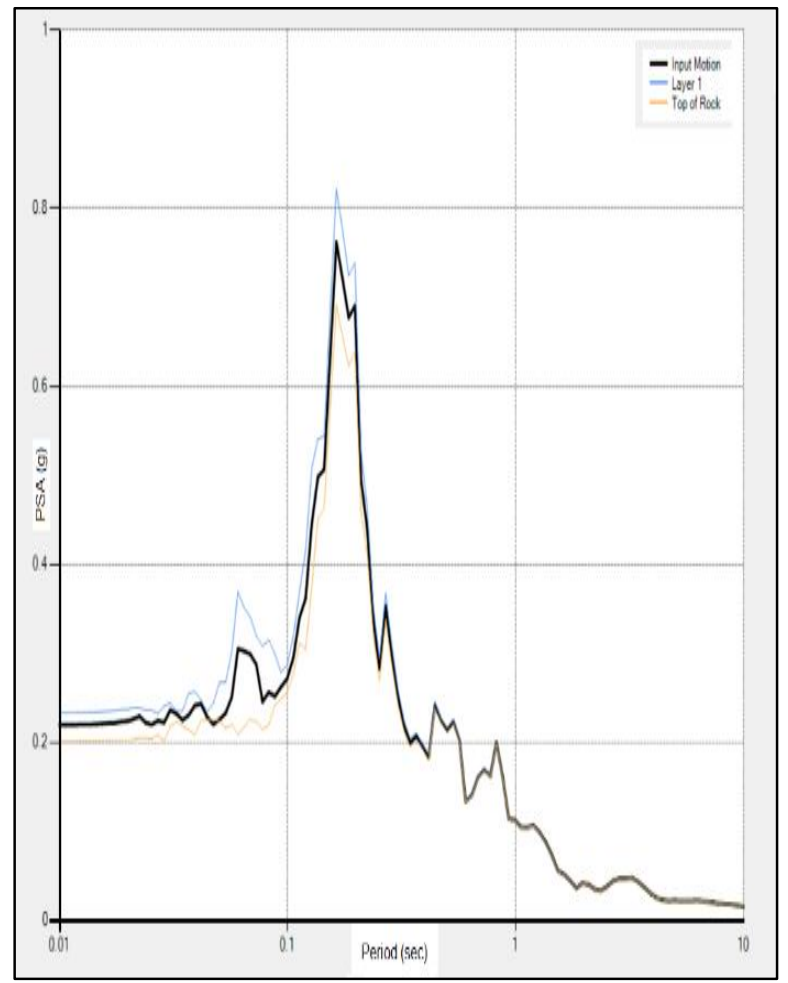

Figure 11. Spectrum-Period, Amplification-Period and PSA-Period plots of Doğantarla region Sis-7 data using Kocaeli earthquake records (Doğantarla bölgesi Sis7'ye ait verilerin, Kocaeli deprem kayttart kullanılarak elde edilen Spektrum-Periyot, Amplifikasyon-Periyot ve PSA-Periyot grafikleri)

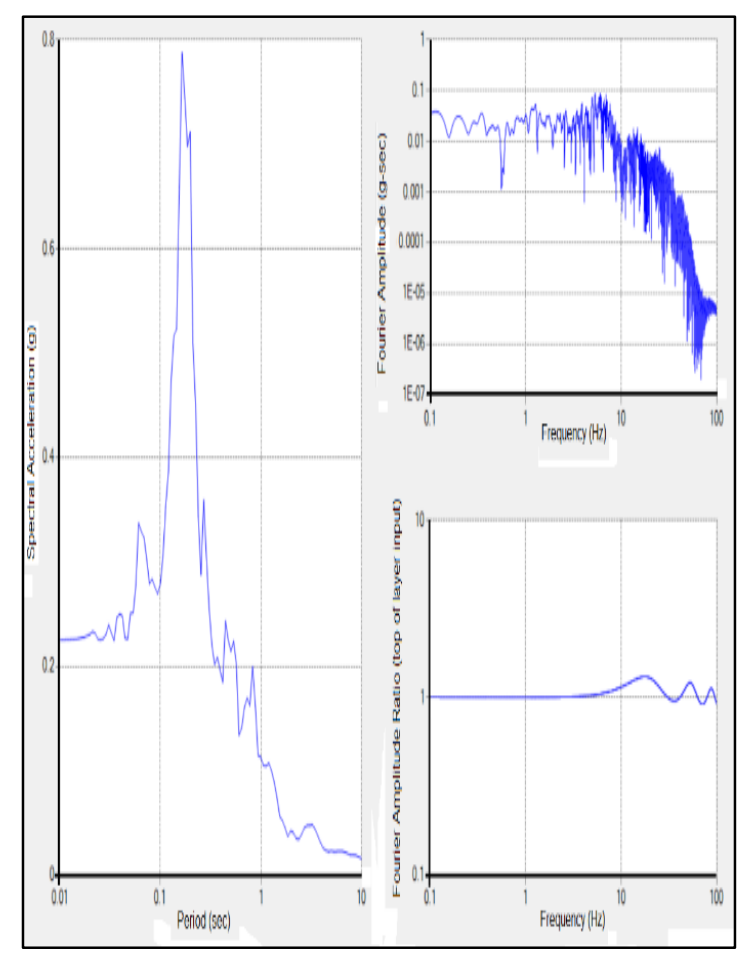




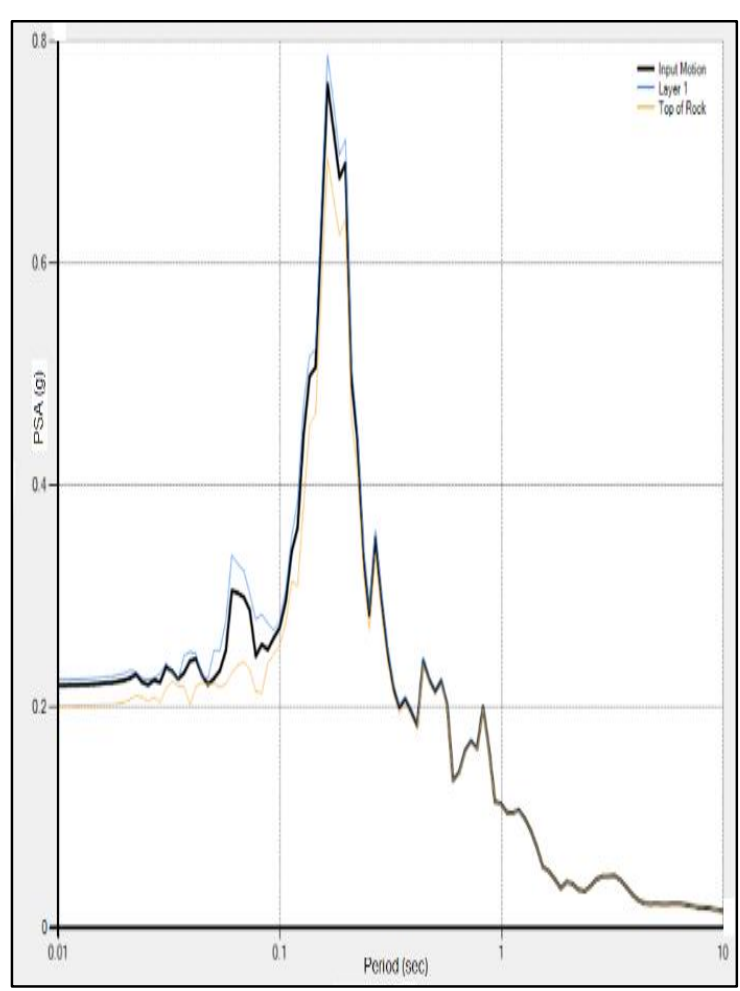

Figure 12. Spectrum-Period, Amplification-Period and PSA-Period plots of Doğantarla region Sis-8 data using Kocaeli earthquake records (Doğantarla bölgesi Sis8 'e ait verilerin, Kocaeli deprem kayttları kullanılarak elde edilen Spektrum-Periyot, Amplifikasyon-Periyot ve PSA-Periyot grafikleri)

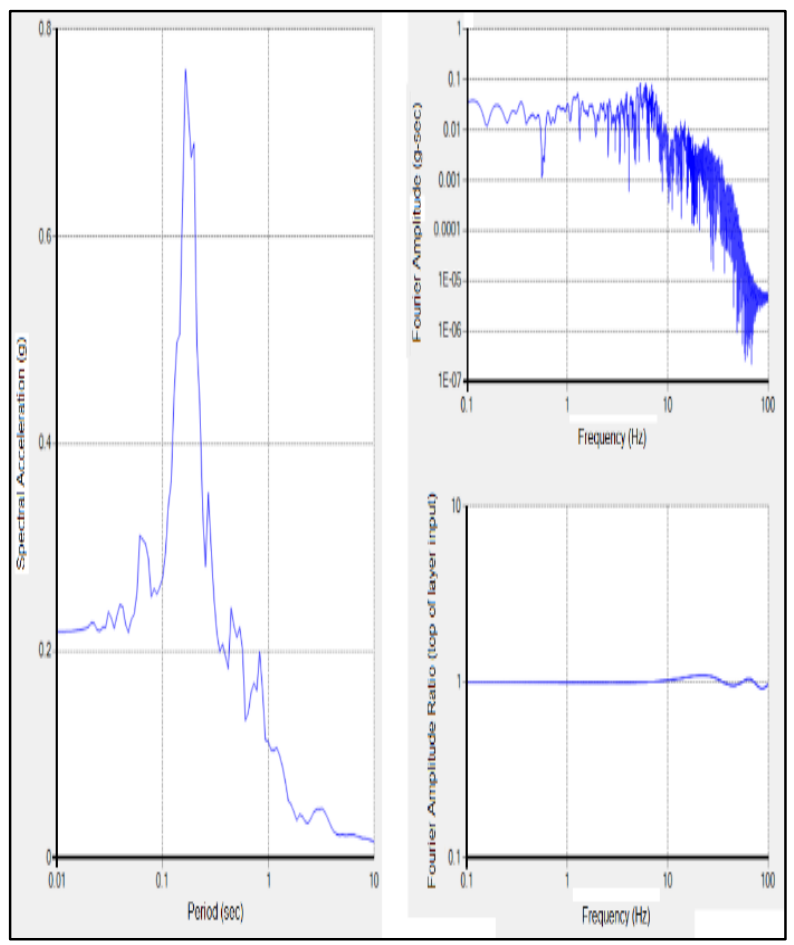

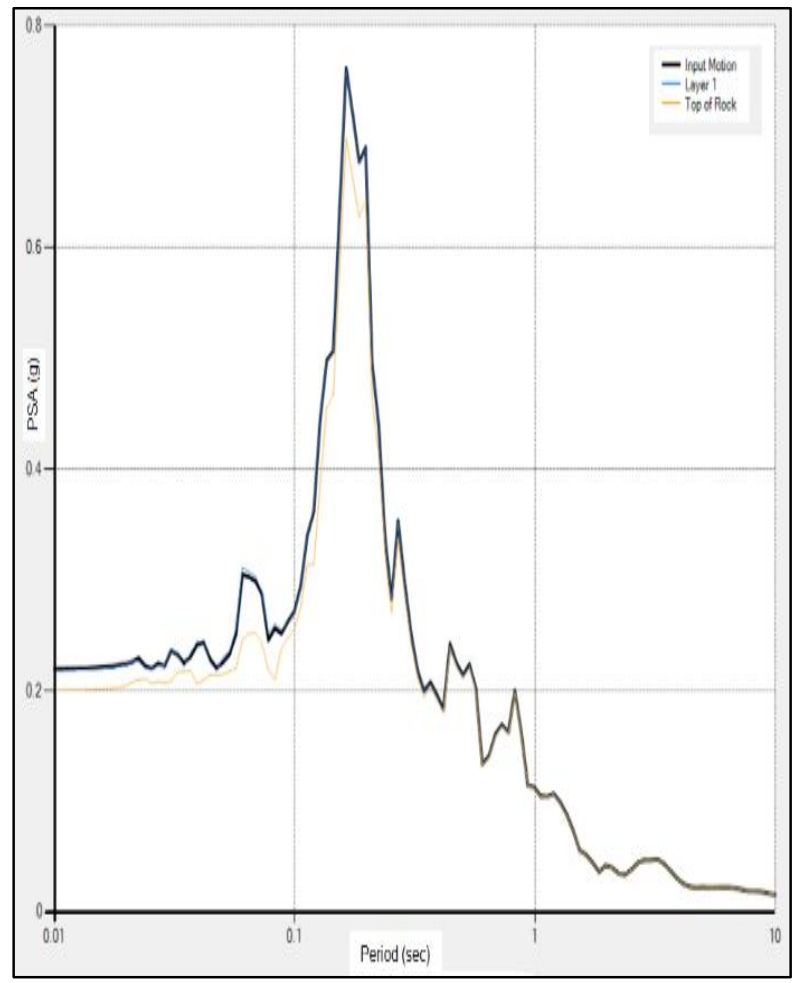

Figure 13. Spectrum-Period, Amplification-Period and PSA-Period plots of Doğantarla region Sis-9 data using Kocaeli earthquake records (Doğantarla bölgesi Sis9'a ait verilerin, Kocaeli deprem kayttları kullanlarak elde edilen Spektrum-Periyot, Amplifikasyon-Periyot ve PSA-Periyot grafikleri)

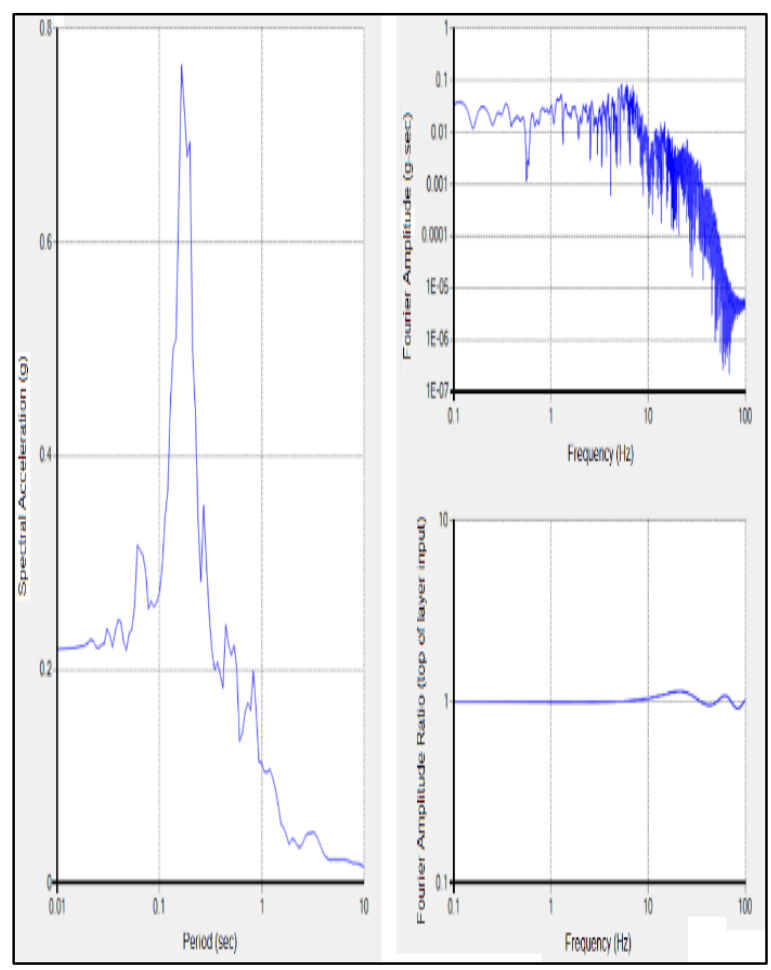




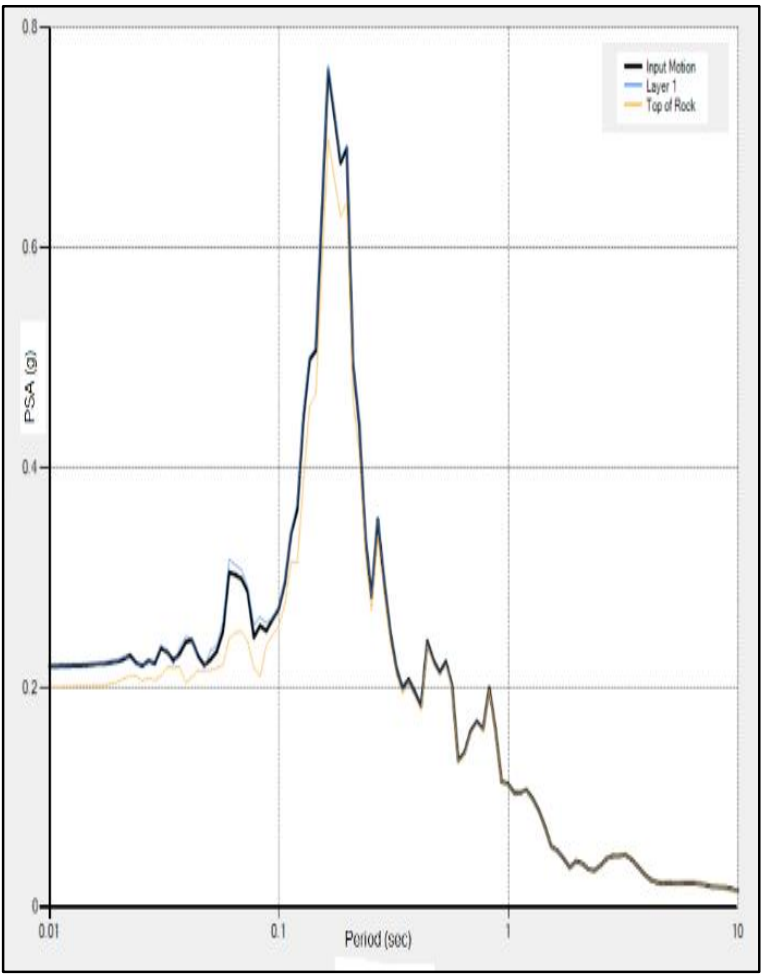

Figure 14. Spectrum-Period, Amplification-Period and PSA-Period plots of Doğantarla region Sis-10 data using Kocaeli earthquake records (Doğantarla bölgesi Sis-10'a ait verilerin, Kocaeli deprem kayıtları kullanılarak elde edilen Spektrum-Periyot, Amplifikasyon-Periyot ve PSAPeriyot grafikleri)

The soundings and seismic study data made in the Doğantarla region of Aksaray province were used and earthquake behavior analyzes were carried out using the DeepSoil program. As a result of these analyzes, it was learned about the possible behavior of the region.

The results obtained in seismic studies were similar throughout the region, causing the results of the analysis to be close. This can be shown as evidence of the correctness of the analysis. As can be seen in the graphics, PSA value is one of the main parameters representing soil dynamic properties in earthquake resistant building design.

PSA is the highest response corresponding to the earthquake acceleration acting. If soil magnification values are evaluated according to the graphics; 0.2 seconds of Sis-1, 0.3 seconds in Sis-2, Sis-3, Sis-4, Sis-6, Sis-7, Sis-8, Sis-9 and Sis-10 and Sis-5 it was observed that PSA reached maximum peak values in 0.4 second. The results of the analysis vary between $0.25 \mathrm{~g}$ with $0.7 \mathrm{~g}$ in Sis-1, $0.2 \mathrm{~g}$ with $0.82 \mathrm{~g}$ in Sis-2, $0.2 \mathrm{~g}$ with $0.76 \mathrm{~g}$ in Sis-3, $0.2 \mathrm{~g}$ with $0.76 \mathrm{~g}$ in Sis-4, $0.2 \mathrm{~g}$ with 0.7 in Sis-5, $0.2 \mathrm{~g}$ with $0.82 \mathrm{~g}$ in Sis-6, 0.2 $\mathrm{g}$ with 0.81 in Sis-7, $0.2 \mathrm{~g}$ with $0.8 \mathrm{~g}$ in Sis-8, $0.2 \mathrm{~g}$ with $0.72 \mathrm{~g}$ with Sis-9 and $0.2 \mathrm{~g}$ with $0.75 \mathrm{~g}$ in Sis-10. According to the results of the analysis, soil enlargement rates vary between $0.5 \mathrm{~g}$ and $0.6 \mathrm{~g}$ according to the seismic study results. When the analyzes are examined, sounding and seismic study data belonging to the same region gave similar results close to each other. This situation is in parallel with the similarity of shear wave velocities and reflects the reliability of the analyzes.

\section{CONCLUSIONS (SONUÇLAR)}

Land and laboratory studies have been carried out on an area of approximately 530.18 hectares in the Doğantarla region of Aksaray province. In this study, the results obtained were analyzed and the seismicity of the region was investigated in the event of a possible earthquake. Within the scope of the study, the engineering properties of the soil, groundwater condition, geotechnical parameters were evaluated using 30 drilling data and 10 seismic working data.

According to the NEHRP-UBC definition, the ground class of the relevant region is "B-C; Rock / Very Firm Hard Ground or Soft Rock" class, according to TS EN 1998-1 (Eurocode 8), “A-B; Rock / Very Tight Sand Gravel / Very Hard Clays".

Due to the rock floors consisting of tuffs in the study area, there are no problems with swelling and seating engineering. Seismicity of the region was investigated by taking into account Vs shear wave velocities, depth and unit volume weight values obtained in the studies.

The earthquake effect can be absorbed by the ground layers, and on the contrary, the magnitude of the earthquake can be increased by increasing the amplitude. Ground magnification values should be determined in order to detect this situation. For this purpose, in the DeepSoil program, as suggested in TBDY (2018), the "Equivalent Linear Analysis" method was chosen based on the earthquake records occurred in 1999 by selecting a 5\% damping ratio and the results were interpreted.

Similar results were found between the analysis results. The analysis results obtained confirm that the region is a 5th degree earthquake zone. As a result of the study, it was seen that the DeepSoil program gave reliable results. 


\section{CONFLICT OF INTEREST STATEMENT (ÇIKAR CATISMASI BILLDIRIMI)}

The authors reported no potential conflict of interest.

\section{REFERENCES (KAYNAKLAR)}

[1] Afet ve Acil Durum Yönetimi Başkanlığı, Türkiye Bina Deprem Yönetmeliği. TBDY, 2018 Ankara: T.C. Cumhurbaşkanlığı Resmi Gazete, 2018.

[2] N. Ö. Aşçı and A. Alkaya, Doğantarla Köyü Jeolojik ve Jeoteknik Inceleme Raporu, Aksaray: TMMOB-Jeoloji Mühendisleri Odası. 2017.

[3] T. Imai and K. Tonouchi, "Correlation of N-value with s-wave velocity and shear modulus", 2nd European Symposium. of Penetration Testing 2/1982 05-24/Amsterdam; NLD; Rotterdam: A.A. Balkema; DA., 1982. pp. 57-72.

[4] D. M., Boore, W. B., Joyner and T.E. Fumal, "Equations for estimating horizontal response spectra and peak acceleration from western north American earthquakes: a summary of recent work," Seismological Research Letters, vol. 68, no. 1, pp. 128-153, January, 1997, doi: https://doi.org/10.1785/gssrl.68.1.128

[5] C. Thornton ((National Earthquake Hazards Reduction Program), Regulations for New Buildings and Other Structures. Washington, D.C.: Building Seismic Safety Council National Institute of Building Sciences, 2003.

[6] TS EN 1998-1, Eurocode 8: Depreme dayanıkl yapıların projelendirilmesi. Ankara: Türk Standardları Enstitüsü, 2005.

[7] A. Y. Elghazouli, Seismic Design of Buildings to Eurocode 8. Boca Raton: CRC Press, 2017.

[8] Y.M.A. Hashash, M.I. Musgrove, J.A. Harmon, O. İlhan, D.R. Groholski, C.A. Philips and D., Park, "DEEPSOIL 6.1, User Manual" http://deepsoil.cee.illinois.edu/ [Online]. Available: http://deepsoil.cee.illinois.edu/Files/DEEPSOIL_Use r_Manual_v6.pdf. [Accessed: June. 12, 2020].

[9] A. Keçeli, "Sismik Yöntemlerle Müsaade Edilebilir Dinamik Zemin Taşıma Kapasitesi ve Oturmasının Saptanması," Jeofizik, cilt 4, sayı 2, s. 83 92,1990
[10] W.M. Telford, L.P. Geldart and R.E. Sheriff, Applied Geophysics. 2nd Edition Cambridge: Cambridge University Press, 770. 1990.

\section{Atila DEMİRÖZ}

Atila Demiröz was born in 1965 in Konya. After graduating from Konya Gazi High School, he went to Konya Selçuk University and completed Civil Engineering at this university in 1988 as Civil Engineer. He joined the master's program in Selçuk University Civil Engineering Department in 2004 and graduated in 1992. He continues his $\mathrm{PhD}$ education in 2004-2008, Selçuk University, Institute of Science, Civil Engineering Department, Konya Selçuk University, PhD education in the field of Geotechnical Engineering. Work areas include geotechnical engineering, foundation engineering and environmental geotechnics.

\section{Raziye BOZKURT}

Raziye Bozkurt was born in Aksaray, 1991. After she graduated from high school in Aksaray, she went to Aksaray University in Aksaray and she completed Civil Engineering Department in this university, in 2012. In 2012, she attended the MSc programme at the Civil Engineering Department in Aksaray University and graduated in 2015. Konya Technical University is continuing her $\mathrm{PhD}$ education in Geotechnical Engineering. Her current fields of research are pile raft foundations, optimization, geotechnical analyzes, earthquake analyzes. 